\title{
Effect of Dennettia Tripetala Powder and Reduced Rates of Pirimiphos-Methyl Singly and Combined in Management of Callosobruchus Maculatus (F.) [Coleoptera: Bruchidae]
}

\author{
Idoko, J. E \\ Department of Crop, Soil and Pest Management \\ School of Agriculture and Agricultural Technology \\ Federal University of Technology Akure, Ondo State
}

Adebayo, R. A. (Corresponding author)

Department of Crop, Soil and Pest Management

School of Agriculture and Agricultural Technology

Federal University of Technology Akure, Ondo State

Tel: 234-70-3866-1128Ｅ-mail: abiodun1400@yahoo.com

Received: June 02, 2010 Accepted: June 18, 2010 doi:10.5539/ijb.v3n2p174

\begin{abstract}
Dennettia tripetala powder and reduced rates of pirimiphos-methyl dust were tested on cowpea against $C$. maculatus for their effective management. The study was conducted under ambient conditions of $25^{\circ} \mathrm{C}-28^{0} \mathrm{C}$ and $65 \%-75 \%$ relative humidity in the laboratory for a period of 3 months. Powder of D. tripetala and dust of pirimiphos-methyl were tested sole at $0.4 \mathrm{~g}$ and $0.1 \mathrm{~g}$ per $20 \mathrm{~g}$ of cowpea seeds respectively while various combinations at $0.2 \mathrm{~g} \mathrm{DT}+0.05 \mathrm{~g}$ PM, $0.2 \mathrm{~g}$ DT $+0.025 \mathrm{~g} \mathrm{PM}$, and $0.2 \mathrm{~g} \mathrm{DT}+0.0013 \mathrm{~g}$ PM were also tested on $20 \mathrm{~g}$ of cowpea seed. D. tripetala powder was more effective at $0.4 \mathrm{~g}$ when applied singly. Adult mortality of more than $80 \%$ occurred in less than 3 days. It also caused a significant reduction in oviposition, adult emergence and weight loss after emergence. Effect of sole application of pirimiphos-methyl dust at $0.1 \mathrm{~g}$ per $20 \mathrm{~g}$ of cowpea seed was less when compared with $0.4 \mathrm{~g}$ of $D$. tripetala. The combined treatments of $D$. tripetala and pirimiphosmethyl slightly reduce adult emergence and weight loss. This study revealed better performance of $D$. tripetala powder when applied singly over reduced rates or even when combined with pirimiphos-methyl against cowpea seed beetle.
\end{abstract}

Keywords: Dennettia tripetala, Pirimiphos-methyl, Oviposition, Powder, Dust, Emergence

\section{Introduction}

Cowpea, Vigna unguiculata (L.) Walp is an important legume crops in tropics and sub-tropics. It assumes a staple position in crop food of Africa and especially in Nigeria where it supplies most of the protein requirement of the diets. A substantial part of the world cowpea production comes from Nigeria with about 4 million hectares and approximately 1.7 million tons of beans annually (Ofuya, 2003). Production of cowpea has however been difficult as a result of attack from cowpea seed beetle, Callosobruchus maculatus (F.). C. maculatus has drawn attention because it is widely distributed throughout the tropical and sub-tropical regions, tropicopolitans (Lale, 2002). Cowpea seed beetle, Callosobruchus maculatus is a cosmopolitan pest of stored grain legumes, especially cowpeas in the tropics and sub-tropics (Jackai \& Daoust, 1986; Ofuya, 2001). Several damaged seeds are disfigured with egg covered and riddled with adult exit holes, consequently have reduced weights and poor germinability, often, after six months in storage $100 \%$ seed infestation may be recorded (Alabeek, 1996). Caswell (1981) reported an estimated of $4.5 \%$ infestation and damage caused by storage bruchids, especially $C$. maculatus. Control of C. maculatus has been through the use of conventional dusts, such as pirimiphos - methyl, permethrin and fumigants such as aluminium phosphate. Their effectiveness against $C$. maculatus storage has been reported by Jackai \& Daoust (1986). When the chemicals are used improperly they poses risk to man and environment, this is most common among uneducated rural farmers in Africa (Ofuya, 2003). Plant derived insecticides could be a better replacement for the synthetic insecticides in stored products protection (Lale, 2001). 
Plant products such as vegetable oils, essential oils, crude extracts and powders have been tested against $C$. maculatus. (Lale, 1995; Dales, 1996; Golob et al., 1991; Boeke et al., 2001). Powder of parts of many indigenous plants when applied at $2 \%$ of the weight of stored beans will effectively control the cowpea seed beetle in storage (Lale, 1994; Ogunwolu \& Odunlami 1996; Adedire \& Lajide, 2001; Ofuya \& Salami, 2002). This study investigated efficacy of combined powders of Dennettia tripetala and dust of pirimiphos-methyl against their sole treatment in the management of cowpea seed beetle, Callosobruchus maculatus.

\section{Materials and Methods}

This study was conducted in the entomology laboratory of the Department of Crop, Soil and Pest Management, Federal University of Technology Akure, Ondo State, Nigeria in 2009.

\subsection{Culturing of Callosobruchus maculatus}

The original Callosobruchus maculatus used was derived from a colony originating from infested cowpea seeds collected from Oja Oba market in Akure, Ondo State, Nigeria. The emerged adults were sub-cultured in the laboratory and the sub-culture was maintained in Kilner jars containing $500 \mathrm{~g}$ beetle susceptible cowpea (Ife-brown) in the laboratory at $28 \pm 3^{\circ} \mathrm{C}$ and $70 \pm 5^{\circ} \%$ relative humidity.

The clean beetle susceptible cowpea seeds (Ife-brown) used for the experiment were obtained from the Agricultural Development Program (ADP) office, Akure. Prior to experiments, the seeds were sterilized for 3 hours in a Gallenkamp oven at a temperature of $60^{\circ} \mathrm{C}$ to kill any available insects and other microorganisms in them (Allotey \& Azalekor, 2000).

\subsection{Preparation of plant material}

Dennetia tripetala seeds used in this study were obtained from Oja-Oba market, Akure Ondo State. Well dried Dennetia tripetala was pulverised using mortar and pestle. It was sieved to obtain fine powder while large fibrous particles were removed and discarded. The fine powder was put in a plastic container with tightly fitted lids and placed in a wooden cupboard in the laboratory for future use.

\subsection{Bioassay of the powder Dennetia tripetala and dust of pirimiphos-methyl}

Twenty grams (20g) of clean beetle susceptible cowpea seeds (Ife-brown) were weighed into petri-dishes each of which $0.4 \mathrm{~g}$ and Dennetia tripetala powder was added separately. Five pairs of adult Callosobruchus maculatus (1-2days old) were introduced into each of the petri-dishes. The contents of the plastic were then shaken vigorously for proper admixture. The experiment was arranged in completely randomized design. Adult mortality was monitored and counted for 3 days after application, after which all the insects were removed. The number of eggs laid on the seeds and adults which emerged from the eggs were counted 21 days post infestation. Treatment and control were replicated three times.

Pirimiphos-methyl dust was tested at a reduced rate of $0.1 \mathrm{~g}$ per $20 \mathrm{~g}$ of cowpea seeds using the procedure described for Dennetia tripetala powder. Three days after infestation, all insects were removed and the number of eggs laid counted and recorded. Number of adults that emerged was also counted 21 days post infestation.

Combined treatment of Dennetia tripetala powder and pirimiphos-methyl dust at different concentrations of $0.2 \mathrm{~g}$ $\mathrm{DT}+0.05 \mathrm{~g}$ PM, 0.2g DT + 0.025g PM, 0.2g DT + 0.0013g PM were all tested on C. maculatus following the same procedure described above. Data on eggs laid, adult emergence, mortality and weight loss after emergence were al monitored and recorded.

\subsection{Statistical analysis}

Data obtained were subjected to analysis of variance (ANOVA) and Genstat software version 5 Release 3.2 (Lawes Agricultural Trust, 1995). Significant differences at $(\mathrm{P}>0.05)$ were separated using Least Significant Difference (LSD). Data on adult mortality were subjected to arcsine transformation while those on adult emergence and weight loss were transformed using square root transformation to normalize the data for analysis.

\section{Results and Discussion}

\subsection{Mortality}

Dennettia tripetala powder and pirimiphos-methyl dust exhibited insecticidal activities on the adult cowpea seed beetles and caused varying degree of mortality. When applied singly $D$. tripetala caused higher mortality (83\%) at 3 days (72hrs) post application of treatment while pirimiphos-methyl dust caused (73\%) mortality, though their difference is not significantly different at $\mathrm{P}>0.05$ (Table 1).

\subsection{Number of egg laid, Adult emergence and Seed weight loss}

Table 2 shows the number of egg laid, adult emergence and seed weight loss. All the treatments were 
significantly different at $\mathrm{P}>0.05$. Fewer numbers of eggs (8) were laid on the cowpea seed treated with $0.4 \mathrm{~g}$ DT compared with higher number (86) recorded for treatment with $0.1 \mathrm{~g}$ PM. More number of adult insect (29) emerged treatment with $0.1 \mathrm{~g}$ PM while less number emerged from seed treated with D. tripetala at $0.4 \mathrm{~g}$. Higher seed weight loss was also recorded on seed treated with 0.1g PM than those treated with $0.4 \mathrm{~g}$ DT and were consequently significantly different. However, control treatment recorded highest number in all the parameter determined.

From Table 3, more percentage mortality $(60 \%)$ was recorded on seeds treated with a combined DT and PM at $0.2 \mathrm{~g}+0.05 \mathrm{~g}$ for $72 \mathrm{hrs}$, although does not show any significant difference from $(53 \%)$ that was obtained from 0.2 $\mathrm{DT}+0.025 \mathrm{PM}$ at $\mathrm{P}>0.05$. However treatment combination at $0.2 \mathrm{DT}+0.0013 \mathrm{PM}$ was significantly different from others with percentage mortality of 46 except control treatment.

Table 4 revealed highest number of egg laid on seed treated with $0.2 \mathrm{~g}$ DT $+0.2 \mathrm{~g}$ PM compared to treatment with $0.2 \mathrm{~g}$ DT $+0.05 \mathrm{~g}$ PM but was not different significantly $(\mathrm{P}>0.05)$. Control treatment has the highest number of egg laid on the cowpea seeds and was significantly different from other treatment combinations. Numbers of adult that emerged and seed weight loss recorded from all the treatments were significantly different.

Sole and combined treatments of $D$. tripetala powder and pirimiphos-methyl dust exerted insecticidal activities on the seed beetle and thus caused varying degrees of mortality. All treatments have negative effects on the beetles when applied thus causing reduction in the number of eggs laid, adult emergence and seed weight loss. Various natural plant products have been used with a good degree of success as protectants against a number of stored product insect pests (Ewete \& Alamu, 1999; Liu \& Ho, 1999; Rajapakse \& van Emden, 1997; Okonkwo $\&$ Okoye, 1996). Previous work on ash of some bioactive plant species showed that it caused mortality, oviposition deterrence and /or ovicidal action resulting in reduced progeny production of stored product insects (Akob \& Ewete, 2007; Abdelgaleil \& Nakatani, 2003). The results of this study also confirmed reports of previous works by (Ofuya, 2001; Lale, 2002) that D. tripetala, pirimiphos-methyl and its mixture has a significant contact toxicity action against $\mathrm{C}$. maculatus. The mechanisms of its protective action against the cowpea seed beetle include direct toxicity to adults (which cause mortality) and eggs and inhibition of oviposition by female beetles. Similar effects of plant materials as crop seeds protectants have been observed in the treatment of cowpea and maize weevils (Asawalam et al., 2007; Ewete et al., 2007; Ofuya \& Dawodu, 2002)

The powder served as contact insecticides and so was able to enter the body when the insects walk or crawl over the treated surface, the insecticides were absorbed through the body wall (Lale, 2002).

\section{Conclusion and Recommendation}

It was observed in this study that sole treatment of Dennettia tripetala manifested significant contact toxicity against cowpea seed beetle more than sole treatments of pirimiphos-methyl and other treatment combinations. Dennettia tripetala reduced number of egg laid, adult that emerged and seed weight loss of treated cowpea seed.

D. tripetala from the viewpoint of this study could be a good candidate to replace synthetic convectional chemicals in the management of insect pests of stored grains as a result of its bioefficacies and availability. When results of sole treatments are compared with combined, this study revealed an antagonistic effects of $D$. tripetala powder and pirimiphos-methyl dust.

Further studies are required to determine various active ingredients available in D. tripetala.

\section{Acknowledgments}

The authors are grateful to Miss. S.T. Adegunlehin for data collection and the Technologists in the laboratory of the Department of Crop, Soil and Pest Management, Federal University of Technology Akure for their assistance.

\section{References}

Adedire, C. O. \& Lajide, L. (2001). Efficacy of powders of some tropical plants in the control of pulse beetle. Applied Tropical Agriculture, 6, 11-15.

Alebeek, F. A. N. (1996). Natural suppression of Bruchid pest in stored cowpea Vigna unguiculata (L) Walp in West Africa. International Journal of Pest Management, 42, 55-60.

Allotey, J. \& Azalekor, W. (2000). Some aspects of the biology and control using botanicals of the rice moth, Corcyra cephalonica (Stainton), on some pulses. J. stored prod. Res., 36 (3), 235-243.

Asawalam, E. F, Emosairue, S. O., Ekeleme, F. \& Wokocha, R. C. (2007). Insecticidal effects of powdered parts of eight Nigerian plant species against maize weevil Sitophilus zeamais Motschulsky (Coleoptera: 
Curculionidae). ElectronicJournal of Environmental, Agriculture and Food Chemistry, 6 (11), 2526-2533.

Boeke, S. J., van Loon, J. J. A., van Huis, A., Kossou, D. K. \& Dicke, M. (2001). The use of plant material to protect stored leguminous seeds against seed beetles: a review 108 pp. Backhuys Publishers, Netherlands.

Caswell, G. H. (1981). Damage to stored cowpea in the Northern of Nigeria. Samaru Journal of Agricultural Research, 1, 11-19.

Dales, M. J. (1996). A review of plant materials used for controlling insect pests of stored products. NRI bulletin 65, Chatham, UK: Natural Resource Institute.

Ewete, F. K., Ashimolowo, O. R. \& Adohi, E. A. (2007). Survey of planta used in maize storage in Abeokuta North Local Government Area and the efficacy of a selected species against Sitophilus zeamais Motschulsky (Coleoptera: Curculionidae). Nigerian Journal of Entomology, 24, 119-126.

Golob, P., Moss, C., Males, M., Fidgen, A. \& Evans, J. (1991). The spices and medicinals as bioactive protectants for grains. 23 pp. FAO, Rome.

Jackai, L. E. N. \& Daoust, R. A. (1986). Insect pests of cowpeas. Annual review of entomology 31, 95- 119.

Lale, N. E. S. (1994). Laboratory assessment of the effectiveness and persistence of powders of four spices on cowpea bruchid and maize weevil in airtight facilities. Samaru Journal of Agricultural Research, 11, 79- 84.

Lale, N. E. S. (1995). An overview of the use of plant products in the management of stored product coleopteran in the tropics. Postharvest News and Information, 6, 69N- 75N.

Lale, N. E. S. (2001). The impact of storage insect pests on post- harvest loss and their management in the Nigeria agricultural system. Nigerian Journal of Experimental and Applied Biology, 2, 231- 239.

Lale, N. E. S. (2002). Stored Product Entomology and Acarology in tropical Africa. Mole publication, Maiduguri, Nigeria. 204 pp.

Lawes Agricultural Trust (1995). Genstat Software Version 5 Release 3.2 for Windows NT (Software for Statistical Analysis), Rothamstead Agricultural Station.

Ofuya, T. I. \& Dawodu E. O. (2002). Aspects of Insecticidal Action of Piper guineense Schum and Thonn Fruit Powders against Callosobruchus maculatus (F.) (Coleoptera: Bruchidae). Nigerian Journal of Entomology, 19, $40-50$.

Ofuya, T. I. (2001). Biology, ecology and control of insect pests of stored legumes in Nigeria, pp24-58, in pests of stored cereals and pulses in Nigeria: Biology, Ecology and Control, edited by T. I. Ofuya \& N. E. S. Lale. Dave Collins publication, Nigeria.

Ofuya, T. I. (2003). Beans, insects and man. Inaugural lecture series 35. The Federal University of Technology, Akure, Nigeria. 45 pp.

Ogunwolu, O. \& Odunlami, A. T. (1996). Suppression of seed bruchids Callosobruchus maculatus (F.) development and damage on cowpea Vigna unguiculata (L) Walp with Zanthoxylum zanthoxyloides (Lam.) Waterm. (Rutaceae) root bark powder when compared with neem seed powder and pirimiphos-methyl. Crop Protection, 15, 603-607.

Table 1. Percentage mortality of C. maculatus treated separately with D. Tripetala powder and pirimiphos-methyl dust

\begin{tabular}{|l|c|c|c|}
\hline & \multicolumn{3}{|c|}{ Percentage mortality (\%) } \\
\hline Treatments (g) & $\mathbf{2 4 h r s}$ & $\mathbf{4 8 h r s}$ & $\mathbf{7 2 h r s}$ \\
\hline 0.4 DT & $23.30 \mathrm{a}$ & $56.67 \mathrm{a}$ & $83.33 \mathrm{a}$ \\
\hline 0.1 PM & $26.67 \mathrm{a}$ & $53.33 \mathrm{a}$ & $73.33 \mathrm{a}$ \\
\hline Control & $10.00 \mathrm{~b}$ & $16.67 \mathrm{~b}$ & $33.33 \mathrm{~b}$ \\
\hline LSD & 8.00 & 9.70 & 10.30 \\
\hline
\end{tabular}

Means followed by the same letter are not significantly different at $5 \%$ level of significance

LSD: Least Significant Difference 
Table 2. Mean egg laid, adult emergence and seed weight loss of $C$. maculatus treated separately with $D$. Tripetala powder and pirimiphos-methyl dust

\begin{tabular}{|l|c|c|c|}
\hline Treatments (g) & Number of egg laid & Adult emergence & Seed weight loss (g) \\
\hline 0.4 DT & $8.67 \mathrm{a}$ & $2.33 \mathrm{c}$ & $0.33 \mathrm{a}$ \\
\hline 0.1 PM & $86.67 \mathrm{~b}$ & $29.67 \mathrm{~b}$ & $0.58 \mathrm{~b}$ \\
\hline Control & $100.00 \mathrm{c}$ & $34.33 \mathrm{a}$ & $3.43 \mathrm{c}$ \\
\hline LSD & 8.00 & 9.70 & 10.30 \\
\hline
\end{tabular}

Means followed by the same letter are not significantly different at $5 \%$ level of significance

LSD: Least Significant Difference

Table 3. Percentage mortality of $C$. maculatus treated with combined D. Tripetala powder and pirimiphos-methyl dust

\begin{tabular}{|l|c|c|c|}
\hline & \multicolumn{3}{|c|}{ Percentage mortality (\%) } \\
\hline Treatments (g) & $\mathbf{2 4 h r s}$ & $\mathbf{4 8 h r s}$ & $\mathbf{7 2 h r s}$ \\
\hline $0.2 \mathrm{DT}+0.05 \mathrm{PM}$ & $23.30 \mathrm{a}$ & $43.33 \mathrm{a}$ & $60.00 \mathrm{a}$ \\
\hline $0.2 \mathrm{DT}+0.025 \mathrm{PM}$ & $16.70 \mathrm{ac}$ & $33.33 \mathrm{a}$ & $53.30 \mathrm{a}$ \\
$0.2 \mathrm{DT}+0.0013 \mathrm{PM}$ & $30.00 \mathrm{~b}$ & $36.67 \mathrm{~b}$ & $46.70 \mathrm{~b}$ \\
\hline Control & $10.00 \mathrm{c}$ & $16.67 \mathrm{c}$ & $33.33 \mathrm{~b}$ \\
\hline LSD & 8.00 & 9.70 & 10.30 \\
\hline
\end{tabular}

Means followed by the same letter are not significantly different at $5 \%$ level of significance

LSD: Least Significant Difference

Table 4. Mean egg laid, adult emergence and seed weight loss of $C$. maculatus treated with combined $D$. Tripetala powder and pirimiphos-methyl dust

\begin{tabular}{|l|c|c|c|}
\hline Treatments (g) & Number of egg laid & Adult emergence & Seed weight loss (g) \\
\hline 0.2 DT +0.05 PM & $66.00 \mathrm{a}$ & $15.33 \mathrm{a}$ & $0.24 \mathrm{a}$ \\
\hline $0.2 \mathrm{DT}+0.025$ PM & $67.33 \mathrm{a}$ & $17.33 \mathrm{~b}$ & $0.58 \mathrm{~b}$ \\
$0.2 \mathrm{DT}+0.0013 \mathrm{PM}$ & $70.00 \mathrm{~b}$ & $20.00 \mathrm{c}$ & $0.30 \mathrm{c}$ \\
\hline Control & $100.00 \mathrm{c}$ & $34.33 \mathrm{~d}$ & $0.72 \mathrm{~d}$ \\
\hline LSD & 2.30 & 2.00 & 0.02 \\
\hline
\end{tabular}

Means followed by the same letter are not significantly different at 5\% level of significance LSD: Least Significant Difference 